\title{
Review Article \\ Effect of Soil Physical State on the Earthworms in Hungary
}

\author{
Marta Birkas, Laszlo Bottlik, Attila Stingli, Csaba Gyuricza, and Márton Jolánkai
}

Institute of Crop Production, Szent Istvan University, 2103 Godollo, Hungary

Correspondence should be addressed to Marta Birkas, birkas.marta@mkk.szie.hu

Received 11 June 2009; Revised 14 September 2009; Accepted 28 January 2010

Academic Editor: Radha D. Kale

Copyright (C) 2010 Marta Birkas et al. This is an open access article distributed under the Creative Commons Attribution License, which permits unrestricted use, distribution, and reproduction in any medium, provided the original work is properly cited.

\begin{abstract}
Hungarian authors have long been discussing the role of earthworms in improving soil productivity. Earthworm counts in our higher quality soils are similar to those found in soils where more attention is paid to earthworm activity. Negative impacts that are independent of farming — such as sustained dry spells in the summer-also affect earthworm counts. Negative impacts that definitely depend on farming include land use causing soil moisture loss, deep stubble treatment leaving the soil without cover, and ploughing in the summer without subsequent pressing. The climate change is having both positive and negative impacts. Weather patterns are causing losses but adopting climate mitigating tillage are generating benefits. In the trials results so far show that tillage focusing on preserving soil moisture, structure, and organic materials, covering the surface in the critical months as well as adequate soil loosening are fundamental pre-requisites for making the soil a favourable habitat for earthworms.
\end{abstract}

\section{Introduction}
"These entirely deaf and blind little creatures do immense good to the soil".

\section{Róbert BALLENEGGER, 1938}

We have a relatively rich technical literature in the field of agriculture in Hungary dealing with the importance of the activities of earthworms, including text from before the birth of Christ, from China, Egypt, and Rome. Some [1-3] refer to Darwin's work dated 1881 [4] as providing more precise data on these soil habitats than those originating from practical observance. Hungarian books written for farmers to improve their skills drew, initially, on works of Roman authorsCato, Columella, Varro, Vergilius-and later on, since the 1800 s, as referred to by Jolánkai [5], on books written by West European authors, Liebig, Lawes, Schultz-Lupitz, Thaer, Wolny, and so forth as well. Works of Hungarian classical authors [6-8] refer to the soil biological life only in general terms but they do not mention earthworms' activity. The science of soil physics developed impressively from the 1920s on. Consequently, authors began to pay increasing attention to soil biological activity in books on tillage and soil science [9-13]. Although the role of earthworms in enhancing the fertility of soils has long been recognised, concrete reports in books on tillage and soil science did not appear until as late as 1938. Ballenegger [1] refers to earthworms as useful beings in the soil. According to Fekete [14] the deep layer of chernozem soils with high humus content results from earthworms' mixing activity. Grábner [2] noted that earthworm casting contains a variety of nutrients for plants (soluble phosphorous, potassium, calcium, magnesium, trace elements) originated from the plant and animal remains they had consumed together with the soil. Kreybig [15] estimated the quantity of earthworm casting to be as much as 7.5-18.2 tonnes per hectare, depending on the suitability of the habitat. Others [16] consider that the quantity of soil passing through earthworm intestines is as much as 25 tonnes per hectare. This is fairly important since the earthworms concentrate the lime what is available in their structures taking it from the bulk soil. Unfortunately, acidic soils are not favourable for earthworms. Sipos [3] noted, in particular, the soil loosening and fertility improving effects of the activities of earthworms. Others [17-20] consider earthworms to be indispensable elements of the chain of what is known as "biocoenosis." The first proponent of biologically based tillage in Hungary, Kemenesy, found higher earthworm activity in undisturbed soils not damaged by traffic and in soils under perennial papilionaceous plants and grasslands than soils subject to frequent disturbance $[17,18]$. He [18] also observed higher 
earthworm numbers under lathyrus grown for being used as green manure. He found soil under conserving tillage to be a good habitat for them, in contrast to ploughing in the summer, creating definitely adverse conditions for earthworms. He noted that earthworms are hard hit both by summer drought and heat alike, finding a $15^{\circ} \mathrm{C}$ soil temperature as being optimal for these organisms. Today they have been observed to have a broader range of tolerance in terms of temperature, but weeks of extremely high temperatures will definitely reduce their activities. Other authors also found, relatively early, the poor habitat value of cloddy and dry soil after ploughing, for instance, Tischler [21]. Kemenesy $[17,18]$ noted that soils in their pristine condition, that have never been disturbed, offer the best habitat for earthworms. Some authors have reported [2225 ] that the application of excessive amounts of chemicals reduce the value of sites as habitat. In land under crops sown by direct seeding where crop protection is limited practically to the application of chemicals, authors still found higher earthworm numbers [26-28]. Accordingly, factors affecting a site's value as a habitat can be assessed only by adopting a complex approach. Wide-ranging tests were carried out by Zicsi $[29,30]$ in Hungary to produce qualitative and quantitative assessments of the earthworm populations in various soil types. In the new publications the authors discuss earthworm counting for the most part as supplementary aspects instead of primary goals of experiments. Between 1996 and 1998 Gyuricza [31,32] assessed earthworm activity in tillage experiments set up in Chromic Luvisol and in Typic Argiudoll between 1996 and 2006, along with László [33] between 1998 and 2006 also in long-term tillage experiments in brown gleyic forest soil. Birkás et al. [34, 35] used earthworms as indicators of the soil state in their soil quality experiment set up in chernozem soils (Calcic Chernozem) and at different sites under field conditions from 1994 on. This study provides an overview of the findings of experiments carried out during recent years.

\section{Earthworm Activities in Soils Cultivated in Different Ways}

There are 40 different earthworm species $[18,25,29]$ in Hungary, the most commonly found species easily found in arable fields and in gardens. The most frequently encountered species is called common earthworm (Lumbricus terrestris), whose specimens dig deep vertical burrows in the soil. Satchell [22] and Lee [23] note that the presence or the absence of earthworms is a rather good indicator of the quality of the soil, so they can be used as biological soil indicators. This particular form of soil quality assessment is also applied by Hungarian scientists in tillage experiments. In comparison to other soil-borne organisms there is a definite relationship between the number of earthworms and the state of the soil, and the-ISO 23611-1:2006-testing methods are relatively simple [33]. Earthworms are collected from underneath a known soil surface area-for example, a quadrant $\left(0.25 \mathrm{~m}^{2}\right)$-after excavating and screening a certain volume of soil. Under Hungary's climatic conditions in
Table 1: Number of earthworms $\left(\mathrm{pcs} \mathrm{m}^{-2}\right.$ ) in the top $20 \mathrm{~cm}$ layer of a brown gleyic forest soil, under maize (Pyhra, 1998-2006, from [33]).

\begin{tabular}{lcccccc}
\hline Tillage variants & 1998 & 2000 & 2002 & 2004 & 2006 & Mean \\
\hline Direct drilling & 54 & 72 & 66 & 88 & 288 & 113.6 \\
Ridge till & 27 & 32 & 42 & 28 & 72 & 40.2 \\
Ploughing & 10 & 12 & 31 & 16 & 56 & 25.0 \\
\hline Years & rainy & dry & rainy & average & average & \\
\hline
\end{tabular}

TABle 2: Earthworms' live weight $\left(\mathrm{g} \mathrm{m}^{-2}\right)$ in the top $20 \mathrm{~cm}$ layer of a brown gleyic forest soil, under maize (Pyhra, 1998-2006, from [33]).

\begin{tabular}{lcccccc}
\hline Tillage variants & 1998 & 2000 & 2002 & 2004 & 2006 & Mean \\
\hline Direct drilling & 52.7 & 24.2 & 55.1 & 64.3 & 217.8 & 82.8 \\
Ridge till & 9.8 & 11.3 & 41.9 & 17.8 & 67.1 & 29.6 \\
Ploughing & 14.7 & 3.5 & 23.8 & 11.7 & 42.3 & 19.2 \\
\hline Years & rainy & dry & rainy & average & average & \\
\hline
\end{tabular}

natural habitats the earthworms that are longer than $5 \mathrm{~mm}$ can be picked out of the soil. In the experiments, counts were taken every 10 days during the period concerned, in six repetitions, from the soil down to depths of $20-30 \mathrm{~cm}$ as appropriate, as a consequence a negligible number of earthworms were not included in the count. The findings of László [33] apply to settling brown gleyic forest soilPyhra, Austria-in the case of three different types of tillage or soil disturbance. Measurements were taken by Lászlóusing the ISO 23611-1:2006 testing method-in mid-June when the soil was well-shaded by maize (Table 1). Since the soil had a good supply of potassium, no potash was applied, and the $\mathrm{P}$ fertiliser dose was between 42 and $112 \mathrm{~kg} \mathrm{ha}^{-1}$ according to the residual supply from the previous year, while the quantity of $\mathrm{N}$ fertiliser was-also according to the soil analysis-between 92 and $154 \mathrm{~kg} \mathrm{ha}^{-1}$ [32], as was fit for the soil concerned. Findings were processed with the aid of nonparametric variance analysis.

In 1998-in a rainy year-two times more earthworms (54) were found in soil under crop sown by direct drilling than in soil after ridge till (27) and 5.4 times more than under conventional tillage (10). In a dry year (2000) the differences were greater, while in another rainy season (2002) they were smaller. In average years (2004 and 2006) the density of earthworms was significantly higher after direct seeding ( 88 and 288) than that counted after the other two types of tillage. The differences also appeared in the five year average figures as well. Significant differences $(7.9992 P<.05)$ were found between the types of tillage. The soil state modified by tillage also affected the live weight of earthworms (Table 2).

In a year of slightly more precipitation than the averageas is favourable for earthworms-László [33] found five times greater total of earthworm live weight (52.7) in soil under direct drilling than in soil under ridge till (9.8) and three and a half times more than in soil under conventional tillage (14.7). Earthworm populations were reduced by less precipitation in dryer years but differences between their populations in soils of different states remained significant. 
TABle 3: Earthworm burrow density $\left(>2 \mathrm{~mm}\right.$ burrows $\left.\mathrm{m}^{-2}\right)$ in the top $20 \mathrm{~cm}$ layer of a brown gleyic forest soil, under maize (Pyhra, 1998-2006, from [33]).

\begin{tabular}{lcccccc}
\hline Tillage variants & 1998 & 2000 & 2002 & 2004 & 2006 & Mean \\
\hline Direct drilling & 374 & 425 & 386 & 407 & 1372 & 592.8 \\
Ridge till & 211 & 293 & 305 & 319 & 584 & 342.4 \\
Ploughing & 97 & 198 & 287 & 113 & 460 & 231.0 \\
\hline Years & rainy & dry & rainy & average & average & \\
\hline
\end{tabular}

In the rainy year 2002 ploughing had a notably positive impact, yet it was still as not as favourable as those treatments involving less soil disturbance. The difference between the earthworm counts in 2006 between different tillage variants was also reflected in the weight of the earthworms. The difference between the live weights of earthworms in soils under different tillage variants was smaller than the difference between the numbers of earthworms counted. László [33] found no significant difference between tillage variants (5.6600 $P>$.05). It was also him who examined burrow numbers (Table 3 ), finding that there were 1.73 times more earthworm burrows than under ridge till and 2.56 times more than in soil under conventional tillage. He found both horizontal and vertical burrows. He found no significant differences between tillage variants $(5.4600 P>.05)$, but he found a close relationship between earthworm density and burrow density $\left(R^{2}=0.79\right)$.

László [33] underlined that in the given gleyic forest soil earthworms favoured soil under direct drilling, that is, less disturbed but adequately loosened soil in terms of the total porosity space. Their other requisites for life, that is, adequate moisture and-even in the dry year of 2000-food were continuously available for them in the soil.

\section{Importance of the Looseness of the Soil and of the Depth of the Loosened Layer}

Earthworm burrows play an important role-as "biopores"-in soils' water, material, and gas transport heat exchange processes $[24,31]$. Horizontal burrows in the top soil layer enable primarily the soil aeration, while deep vertical earthworm burrows enabling the seeping of water into the soil function as important gravitational pores, making it possible, for instance, for quick transport of sudden downpours to deeper layers of the soil $[33,36$, 37]. According to László [33] vertical earthworm burrows mitigate erosion in sloping sites as run-off is reduced by improved water absorption. Birkás [34] considered that a certain looseness of the soil is a prerequisite for the particular soil loosening activity of earthworms. This was concluded from findings of field experiments set up in the 1990s on various soil types-brown forest, chernozem, and meadow alluvial—by three different clay content levels (Table 4).

The earthworm count was an important factor in addition to monitoring soil state changes in the experiments whose results are summed up in Table 4. The three different clay content levels applied to three different soil types (forest, chernozem, and meadow alluvial) with humus contents of $1.8 \%, 3.1 \%$ and $3.4 \%$, respectively. Ten to fifteen, years ago farmers did not consider earthworms to be of particular importance, therefore according to Birkás [34] the maximum of 36 earthworms (per $\mathrm{m}^{-2}$ ) in the chernozem soil is to be considered to be very good. Incidentally, this was the soil in which the largest numbers of earthworms were found regardless of the soil states. According to the ranking based on earthworm counts undisturbed and deeply loosened soil state is the most favourable under a high $(55 \%)$ cover. More deeply loosened soil with medium (35\%) coverage was the 2nd in the rank, followed by shallower loosened layer and medium coverage. Ploughed soil came as the 5th in the rank, despite the fact that ploughing put the largest amount of plant residues in the soil $\left(5 \mathrm{tha}^{-1}\right)$, but inverting in the same depth was not found to be advantageous. Ploughed soil turned into a particularly disadvantageous habitat when not even field residues were mixed into the soil. Birkás [34] underlined that a compact tillage pan is not suitable for earthworms at all (more deeply loosened state was favourable for maize, surface cover was not, but a compact state was disadvantageous). Tests showed the importance of covering the soil-from the aspect of the earthworm habitat - therefore this factor was also taken into account in other experiments.

\section{The Importance of Surface Cover}

In an experiment conducted by Birkás et al. [38-41] the soil surface was covered as follows: ploughing $0 \%$, loosening, disking $25 \%$, tillage with cultivator $35 \%$, and direct seeding $65 \%$. These coverage ratios were kept up regardless of crops (2002: mustard, 2003: wheat, rye, 2004: rye, pea, 2005: wheat, mustard, 2006: wheat, phacelia, 2007: maize, and 2008: sunflower). The authors found earthworm counts increasing in parallel with increasing coverage ratios. On the other hand, some increase was found in all types of tillage during the first 5 years, thereafter earthworm counts dropped. The authors concluded that densely sown cropseared cereals as main crops, followed by catch crops-created more favourable conditions, while more wide row crops created slightly less favourable conditions as a consequence of the modest shading such plants provide. In order to enable a more accurate evaluation the authors sought for a relationship between the depth of soil disturbance, soil coverage and typical earthworm counts (Table 5).

The authors found that increasing depth-that is favourable habitat at lower depths-, is favourable in the case of every mulch variant. Smaller numbers of earthworms were found under bare surface, almost in all cases, than under various percentages of coverage. The earthworm count under direct drilling was higher than in ploughed soils, as found by many other authors [28, 32, 33]. If, however, soils disturbed to greater depths were covered, even after ploughing, they were found to be better than settled soils. In the case of coverage between $0 \%$ and $25 \%$, between $0 \%$ and $35 \%$, and between $0 \%$ and $65 \%$, an average of $28 \%, 43 \%$, and $67 \%$, respectively, were found in favour of the higher 
TABLE 4: Relationship between the soil clay content, soil state, and earthworm count, under maize (1994-1999, June [34]).

\begin{tabular}{|c|c|c|c|}
\hline 30 & $\begin{array}{l}\text { Clay } \%, \mathrm{v} / \mathrm{v} \\
50 \\
\text { Earthworm count per } \mathrm{m}^{2}(0-20 \mathrm{~cm})\end{array}$ & 60 & $\begin{array}{l}\text { Rank of soil states based on } \\
\text { earthworm counts }\end{array}$ \\
\hline 26 & 36 & 28 & $\begin{array}{l}\text { (1) Undisturbed soil, loosened to } \\
\text { a depth of } 45 \mathrm{~cm} \text {, covered to an } \\
\text { extent of } 55 \%\end{array}$ \\
\hline 25 & 34 & 26 & $\begin{array}{l}\text { (2) Soil loosened down to } 40 \mathrm{~cm} \text {, } \\
\text { covered up to } 35 \% \text { (plant residue } \\
\text { mixed in the soil: } 3 \mathrm{tha}^{-1} \text { ) }\end{array}$ \\
\hline 24 & 30 & 26 & $\begin{array}{l}\text { (3) Soil tilled with cultivator to a } \\
\text { depth of } 18-22 \mathrm{~cm} \text {, under } 35 \% \\
\text { coverage (plant residue mixed in } \\
\text { the soil: } 3 \mathrm{tha}^{-1} \text { ) }\end{array}$ \\
\hline 21 & 26 & 23 & $\begin{array}{l}\text { (4) Soil tilled with cultivator to a } \\
\text { depth of } 16-18 \mathrm{~cm} \text {, under } 20 \% \\
\text { coverage (plant residue mixed in } \\
\text { the soil: } 3 \mathrm{tha}^{-1} \text { ) }\end{array}$ \\
\hline 16 & 22 & 16 & $\begin{array}{l}\text { (5) Soil ploughed to a depth of } \\
22-25 \mathrm{~cm} \text { (plant residue inverted } \\
\left.\text { to the soil: } 5 \mathrm{t} \mathrm{ha}^{-1}\right)\end{array}$ \\
\hline 16 & 20 & 9 & $\begin{array}{l}\text { (6) Undisturbed, uncovered, } \\
\text { settled soil (field residues } \\
\text { removed) }\end{array}$ \\
\hline 6 & 10 & 7 & $\begin{array}{l}\text { (7) Soil ploughed to a depth of } \\
22-25 \mathrm{~cm} \text { (plant residues } \\
\text { removed) }\end{array}$ \\
\hline 0 & 0 & 0 & (8) Plough pan and disk pan \\
\hline 1.786 & 1.908 & 1.216 & $\mathrm{LSD}_{5 \%}$ \\
\hline
\end{tabular}

TABLE 5: Effects of depth of soil disturbance and soil coverage on earthworm count (in loam soil of $19 \%-22 \%$, w/w soil moisture contents as an average of 6 repetitions).

\begin{tabular}{lccccc}
\hline \multirow{2}{*}{ Tillage depth (cm) } & \multicolumn{5}{c}{ Mulch \% } \\
& 0 & 25 & 35 & 65 & Mean \\
\hline $0-5$ & 14 & 18 & 20 & 21 & 18 \\
$16-20$ & 24 & 24 & 27 & 31 & 26 \\
$20-25$ & 22 & 31 & 32 & 39 & 31 \\
$30-35$ & 25 & 34 & 41 & 47 & 37 \\
\hline Mean & 21 & 27 & 30 & 35 & \\
LSD & \\
Between different tillage depths under identical mulch treatment: 3.44 \\
Between different tillage depths as an average of the mulch variants: 2.06 \\
Between mulch variants under the identical depth treatments: 4.977 \\
Between mulch variants as an average of depths: 4.146 \\
Between two depth variants in the case of different mulch percentages: 4.670 \\
Tillage depth: $P$ > .1\%; Mulch \%: $P$ > .1\%; Depth $\times$ Mulch: $P>1 \%$.
\end{tabular}

coverage rates. Deeper disturbance increased earthworm counts by $44 \%, 72 \%$, and $105 \%$-in the order presented in the left-hand-side column in Table 5-, respectively, creating better habitats accordingly. It should also be noted that along with the increasing depth the amount of food for earthworms (that is, the mass of field residue) also increased, except in soils under direct drilling. The authors noted that the amount of field residue mixed in the soil equalled, on an average and per year, 0.2 (only in the case of direct drilling), 3.0, 3.7, and $4.3 \mathrm{tha}^{-1}$ [41]. Eventually, the authors established a close relationship between the depth of disturbance, the ratio of coverage, and the earthworm counts. The tillage-mulch interaction was reliable at a $P=$ $1 \%$ level. They assumed that increased soil cover makes it possible to decrease tillage interventions by a reasonable measure. This was also confirmed by the study carried out in their stubble trial [42].

\section{The Importance of Soil Moisture}

As has been described above, earthworms favour soils loosened to increased depths. Soil coverage is also an important habitat as covered soil is less exposed to the risk of damage by heat or water stress and it also helps the soil keep its moisture content.

In their experiment Birkás et al. [40, 41] were seeking to identify the relationship between soil moisture and earthworm count. The data have been presented merely as an illustration, without supplementing them by a mathematical evaluation. The optimum moisture range for tillage of chernozem soil that is moderately prone to compactingnear the town of Hatvan-is between 19\%, w/w and $25 \%$, 
$\mathrm{w} / \mathrm{w}$, with the optimum being $22 \%$, w/w which is when tillage takes the smallest energy input, but this is also the soil moisture content preferred by earthworms. The authors found that during the period between 2003 and 2008 the shortage of water varied between $5 \%$ and $25 \%$, but it was characteristically affected by tillage variants (Figure 1). The shortage of water had the smallest impact on ploughed soil, followed by direct drilling, while the greatest shortage of water was found in soil after disking. In the average of six successive years the earthworm number was the smallest in disked soil (35), hardly more (36) in ploughed soil. The number of earthworms in soil under direct drilling was 40 on an average, slightly more in soil loosened to a depth of $40 \mathrm{~cm}$ (43), while the highest (48) count was found in soil loosened with cultivator to a depth of $20 \mathrm{~cm}$. The authors found $[38,40]$ that in the case of water shortage not heavily restricting cropping, earthworm activity, and so forth, other factors - for example, soil cover and the required loosenesswill have increased impacts.

Accordingly, supplementary studies were carried out in the experiment site, involving soils of 8 different depths of the loosened layer and three different levels of soil moisture content. In any given soil an $11 \%$, w/w soil moisture content qualifies as dry, while $22 \%, w / w$ and $28 \%$, w/w qualify as humid and wet, respectively. The findings are presented in Figure 2.

Clearly, a $30-40 \mathrm{~cm}$ loosened layer and humid soil are the most favourable for earthworms in any given type of soil. If the soil is dry, a deeper loosened layer makes it more likely for earthworms to be able to survive the dry period (earthworms were found in a state of the rest). A shallow loosened layer combined with high moisture content was found to be the least favourable for earthworms.

\section{The Soil Structural State, with a View in Particular to the Crumb Structure}

The agronomical structure-the relative proportions of clods $(>10 \mathrm{~mm})$, aggregates $(0.25-10 \mathrm{~mm})$, and dust $(<0.25 \mathrm{~mm})$-is suitable for assessing the effects of tillage and the trends in the condition of the soil (improving, unchanged, and deteriorating) [43]. The aggregate fraction can be divided into fractions of small $(0.25-2.5 \mathrm{~mm})$ and large crumbs $(2.5-10 \mathrm{~mm})$. In an experiment carried out by Birkás et al. in the Hatvan region on chernozem soils [40] the growing of densely sown crops entailed steadily increasing earthworm activity, which is likely to be related to the increasingly crumby structure of the soil (Figure 3 ). According to the authors, the earthworm activity and the ratio of crumbs dropped during years in which wide-row crops were grown.

This is the very reason why the authors were looking to establish a relationship between tillage (loosened layer) depth, the trend of crumb forming, and the trend of the changes in earthworm counts (Figure 4). They found that the depth of the loosened layer has an impact on crumb forming $(R=0.76)$, but other factors also play an important role. Earthworm counts varied between 26 and 49 . As the loosened

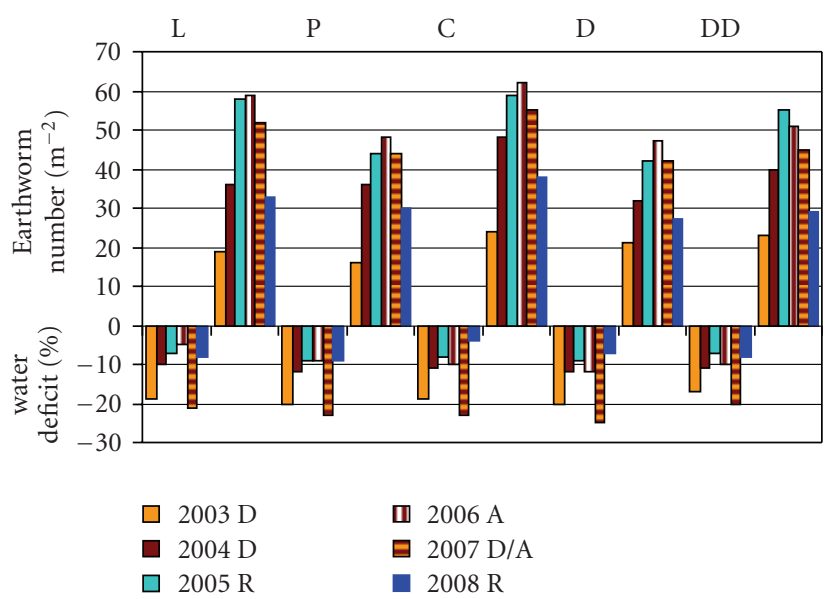

Figure 1: Coherence between water deficit of soil and earthworm number (Hatvan, 2002-2008). Legend: A: average season, D: dry, R: rainy, D/A: dry and average in one season, L: loosening $40 \mathrm{~cm}, \mathrm{P}$ : ploughing $30 \mathrm{~cm}, \mathrm{C}$ : cultivator use $20 \mathrm{~cm}, \mathrm{D}$ : disk tillage $16 \mathrm{~cm}$, and DD: direct drilling.

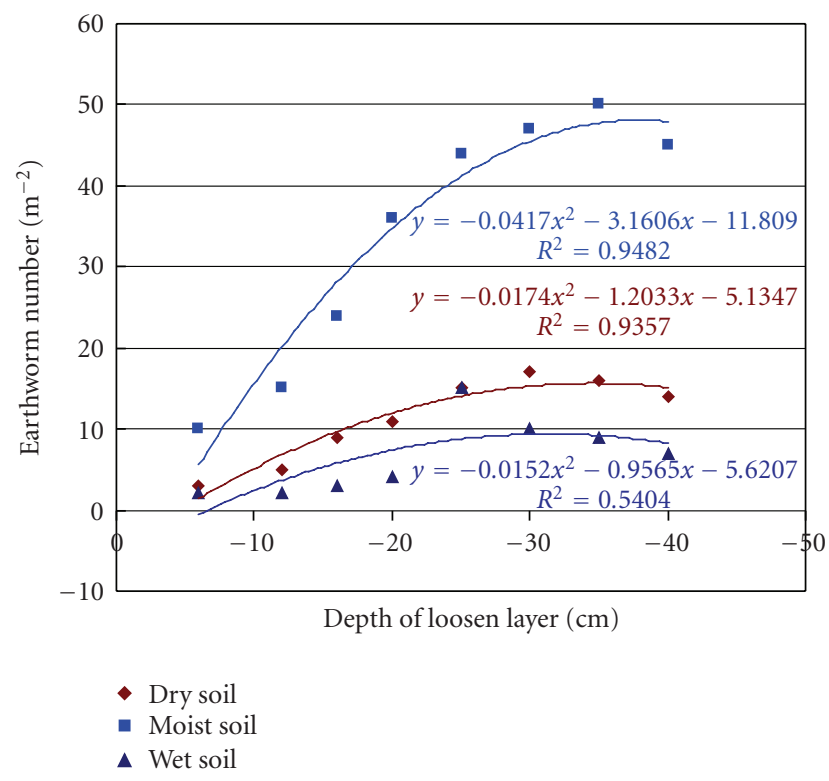

Figure 2: The depth of the loosened layer and the earthworm counts at three different soil moisture levels, in a loam soil.

layer increased earthworm counts increased too to a certain depth $(30 \mathrm{~cm})$, but after a certain depth the earthworm declined slightly. The $R$ value (0.82) shows a considerably close relationship, but it also indicates that the evaluation should be extended to another factor (soil coverage) as well.

\section{More Earthworms, Better Soil Condition}

This study was carried out as a survey, to provide lead information. The authors hope that earthworm activity studies will increase in importance in tillage research in Hungary. The authors performed no ecological separation, on the 


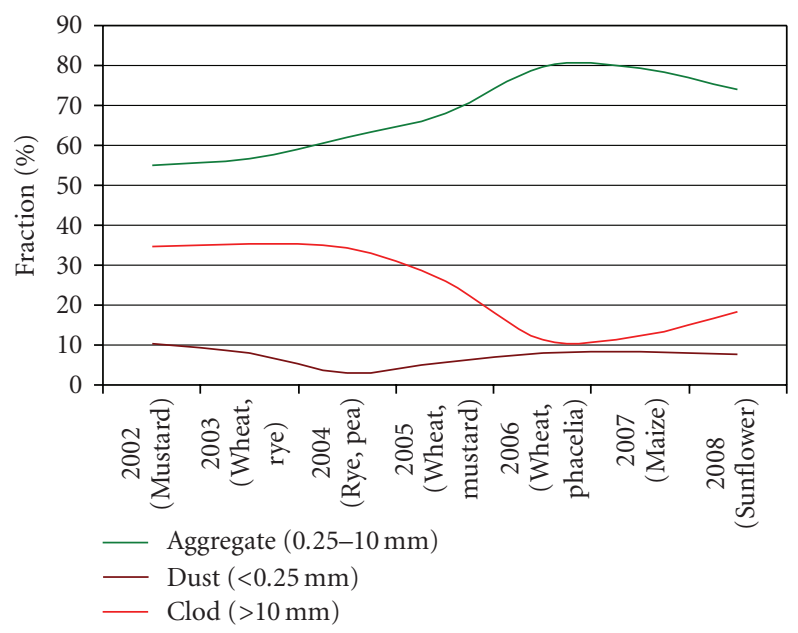

FIgURE 3: The trend of crumb forming in the average of 6 tillage variants, under different crops (Hatvan, 2002-2008, From Birkás et al. [41]).

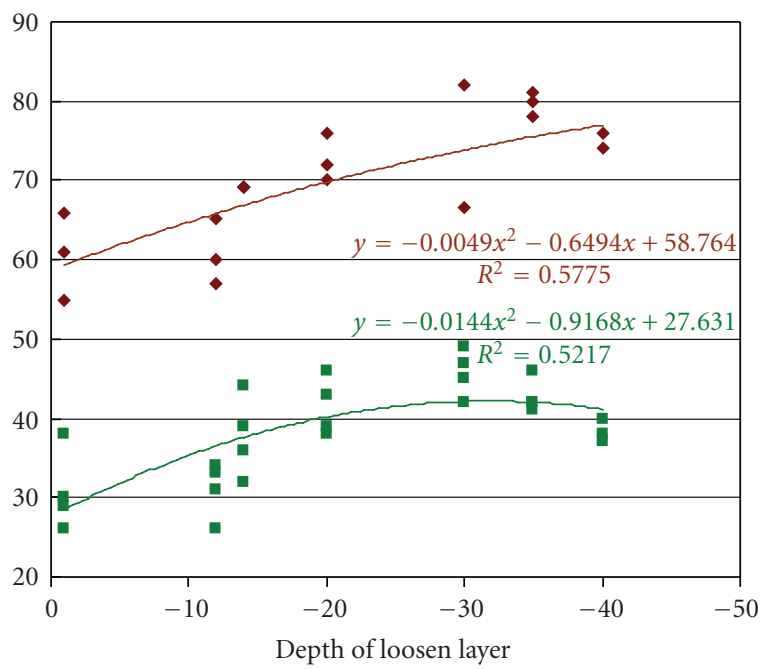

- Aggregate (\%)

- Earthworm number

Figure 4: Relationships between the depth of the loosened layer $(n=7)$, crumb forming $(n=21)$, and earthworm counts $(n=$ 28 ) in soils of favourable soil moisture contents $(19-22 \%, w / w)$. (Hatvan, 2002-2008).

basis of the photos and site descriptions the earthworms counted probably fall in the anecic and the endogenic groups. Earthworm counts in well-tended soils in Hungary are similar to those measured in West European countries and in the USA.

The amount of the application of fertilisers and chemicals never reached the levels prevailing in countries with advanced agriculture sectors. By examining soils under sugar beets Birkás [44] found that in the case of reasonable application of chemicals the quality of tillage and mulch cover affected earthworm counts primarily. Tillage-soil disturbance-however, had a larger than expected impact. The earlier applied deep stubble tillage practices without surface mulching and ploughing in the summer without surface press [45] were likely to have reduced earthworm activity for quite some time. Moreover, the same mistakes were repeatedly made in the same fields $[45,46]$. The climate change has had both negative and positive impacts in Hungary. Extreme weather patterns are causing losses but the recognition of the necessity and the application of climate damage mitigating tillage have been found to have favourable impacts on soils as well [41]. During recent years in soils under conservation tillage, under $15 \%-25 \%$ mulch coverage even after sowing, 6-8 earthworms were found under every plant grown in wide rows, after harvest. It should also be mentioned that no earthworms at all were found in soils of damaged structure. Accordingly, the solution-including increased earthworm activity-is offered by preserving the quality of the soil and mitigating the damage to be caused by climate conditions [46]. Results achieved so far show that soil moisture, structure, and organic material conserving tillage, covering the soil surface during the critical summer months and maintaining adequate looseness are essential prerequisites for making the soil a suitable habitat for earthworms as well.

\section{Conclusions}

Earthworms have been duly appreciated in technical literature in Hungary but precious little research has been focused on them. In tillage experiments supplementary types of evaluations have been produced concerning the relationships between earthworm count, depth of loosened layer, soil moisture, and soil surface cover. The authors found that earthworm-friendly tillage results in loosening and crumb forming, it creates minimised soil surface and is characterised by mulch cover on the soil. The depth of the layer loosened by tillage should be around $30-40 \mathrm{~cm}$ and it may even be shallower (even as shallow as $20 \mathrm{~cm}$ ) if there is no compact tillage pan underneath the tilled layer.

Soil moisture content that makes the soil workable is also favourable for earthworms. Soil surface coverage may increase in importance in the future, during the warm and hot summer months. An at least $35 \%$ soil coverage is necessary, but the optimum is as high as $45 \%$. Field residues mixed into the soil serve as food for earthworms therefore shortage of that is just as disadvantageous as a large, inadequately distributed mass. Climate damage mitigating tillage produces habitats favourable for earthworms as well.

\section{Acknowledgments}

This paper presents results of research programmes supported by NTTIJM08, CRO-33/2007, and HR-43/2008, and our thanks are also to the Experimental and Training Farm of Hatvan, Mezőhegyesi Ménesbirtok Zrt; Belvárdgyulai Mg. Zrt; Agroszen Kft. Szentgál, Róna Kft. Hódmezővásárhely. 


\section{References}

[1] R. Ballenegger, Termőföldünk, Királyi Magyar Természettudományi Társulat, Budapest, Hungary, 1938.

[2] E. Grábner, Szántóföldi Növénytermesztés, Mezőgazdasági, Budapest, Hungary, 1948.

[3] G. Sipos, Földmúveléstan, Mezőgazdasági, Budapest, Hungary, 1962.

[4] C. Darwin, The Formation of Vegetable Mould through the Action of Worm, John Murray, London, UK, 1881.

[5] M. Jolánkai, "A földmúvelés fejlődésének rövid története," in Földmúvelés és Földhasználat, pp. 15-21, Mezőgazda, Budapest, Hungary, 2006.

[6] F. Pethe, Pallérozott Mezei Gazdaság, Szász A. Könyvnyomda, Sopron, Hungary, 1805.

[7] J. Nagyváthy, Magyar Practicus Termesztó, Trattner J. Nyomda, Pest, Hungary, 1821.

[8] S. Cserháti, Általános Növénytermelés, Czéh S. Könyvnyomda, Magyar-Óvár, Hungary, 1900.

[9] K. Kolbai, A Helyes Talajmúvelés, Athenaeum Nyomda, Budapest, Hungary, 1944.

[10] S. Sipos, “Talajmúvelés," in Földmüveléstan, J. Lőrincz, Ed., Mezőgazdasági, Budapest, Hungary, 1978.

[11] G. Füleky, "A Földigiliszták," in Talajtan, P. Stefanovits, G. Filep, and G. Füleky, Eds., Mezőgazda, Budapest, Hungary, 1999.

[12] M. Demo, et al., Obrábanie Pódy, VSP, Nitra, Slovakia, 1995.

[13] K. Kovac, et al., Vseobecná Rastlinná Vyroba, SPU, Nitra, Slovakia, 2003.

[14] Z. Fekete, Talajtan, Mezőgazdasági, Budapest, Hungary, 1952.

[15] L. Kreybig, Az Agrotechnika Tényezői és Irányelvei, Akadémiai, Budapest, Hungary, 1956.

[16] J. Di Gléria, A. Klimes-Szik, and M. Dvoracsek, Talajfizika és Talajkolloidika, Akadémiai, Budapest, Hungary, 1957.

[17] E. Kemenesy, Talajerógazdálkodás, Akadémiai, Budapest, Hungary, 1956.

[18] E. Kemenesy, A Földmúvelés Irányelvei, Akadémiai, Budapest, Hungary, 1961.

[19] E. Kemenesy, Talajmúvelés, Mezőgazdasági, Budapest, Hungary, 1964.

[20] G. Füleky, A Talaj, Gondolat, Budapest, Hungary, 1988.

[21] W. Tischler, "Effect of agricultural practices on the soil fauna," in Soil Zoology: Proceedings of the University of Nottingham Second Easter School in Agricultural Science, pp. 215-230, 1955.

[22] J. E. Satchell, Ed., Earthworm Ecology: From Darwin to Vermiculture, Chapman \& Hall, London, UK, 1983.

[23] K. E. Lee, Earthworms: Their Ecology and Relationships with Soils and Land Use, Academic Press, Sydney, Australia, 1985.

[24] C. A. Edwards and P. J. Bohlen, Biology and Ecology of Earthworms, Chapman and Hall, London, UK, 3rd edition, 1996.

[25] C. Gyuricza, "A kedvezó talajállapot biológiai feltételei. A földigiliszták," Agrofórum, vol. 10, no. 7, pp. 8-10, 1999.

[26] A. D. Mackay and E. J. Kladivko, "Earthworms and rate of breakdown of soybean and maize residues in soil," Soil Biology and Biochemistry, vol. 17, no. 6, pp. 851-857, 1985.

[27] E. J. Kladivko, A. D. Mackay, and J. M. Bradford, "Earthworms as a factor in the reduction of soil crusting," Soil Science Society of America Journal, vol. 50, no. 1, pp. 191-196, 1986.

[28] G. L. Willoughby, E. J. Kladivko, and M. Reza Savabi, "Seasonal variations in infiltration rate under no-till and conventional (disk) tillage systems as affected by Lumbricus terrestris activity," Soil Biology and Biochemistry, vol. 29, no. 3-4, pp. 481-484, 1997.
[29] A. Zicsi, "Determination of number and size of sampling unit for estimating lumbricid populations of arable soils," in Progress in Soil Zoology, P. W. Murphy, Ed., pp. 68-71, Butterworth, London, UK, 1958.

[30] A. Zicsi, A struktúra és a funkció kapcsolata terresztrikus ökoszisztémák tevékenysége tükrében, Doktori értekezés, Budapest, Hungary, 1974.

[31] C. Gyuricza, Az értékőrző és hagyományos talajmúvelés egyes fizikai és biológiai hatásainak értékelése, Doktori értekezés, Gödöllő, Hungary, 2000.

[32] C. Gyuricza, P. Liebhard, and J. Rosner, "Talajökológiai tényezők vizsgálata talajmúvelési tartamkísérletben," in Talajhasználat, Múveléshatás, Talajnedvesség, M. Birkás and C. Gyuricza, Eds., pp. 96-112, Quality-Press Nyomda, Budapest, Hungary, 2004.

[33] P. László, A direktvetéses és a bakhátas vetési és múvelési rendszer hatása a talaj fizikai és biológiai állapotára, Doktori értekezés, Gödöllő, Hungary, 2007.

[34] M. Birkás, A talajtömörödés helyzete Magyarországon, következményei, megelózése és enyhitése, DSc dissertation, Budapest, Hungary, 2000.

[35] M. Birkás, M. Jolánkai, C. Gyuricza, and A. Percze, "Tillage effects on compaction, earthworms and other soil quality indicators in Hungary," Soil and Tillage Research, vol. 78, no. 2, pp. 185-196, 2004.

[36] J. E. Zachmamm, D. R. Linden, and C. E. Clapp, "Macroporous infiltration and redistribution as affected by earthworms, tillage, and residue," Soil Science Society of America Journal, vol. 51, no. 6, pp. 1580-1586, 1987.

[37] I. M. Szabó, Az Általános Talajtan Biológiai Alapjai, Mundus, Budapest, Hungary, 3rd edition, 2008.

[38] M. Birkás, A. Dexter, T. Kalmár, and L. Bottlik, "Soil qualitysoil condition-production stability," Cereal Research Communications, vol. 34, no. 1, pp. 135-138, 2006.

[39] M. Birkás, T. Kalmár, L. Bottlik, and T. Takács, "Importance of soil quality in environment protection," Agriculturae Conspectus Scientificus, vol. 72, no. 1, pp. 21-26, 2007.

[40] M. Birkás, A. Stingli, A. Szemők, T. Kalmár, and L. Bottlik, "Soil condition and plant interrelations in dry years," Cereal Research Communications, vol. 36, supplement, pp. 15-18, 2008.

[41] M. Birkás, M. Jolánkai, and R. Schmidt, "Environmentallysound adaptable tillage - solutions from Hungary," in Proceedings of the 1st Scientific Agronomic Days, M. Hrubá, et al., Ed., pp. 191-194, Nitra, Slovakia, November 2008.

[42] T. Kalmár, M. Birkás, A. Stingli, and K. Bencsik, "Tarlómúvelési módszerek hatékonysága szélsőséges idényekben,” Növénytermelés, vol. 56, no. 5-6, pp. 263279, 2007.

[43] M. Birkás, M. Jolánkai, I. Kisić, and B. Stipešević, "Soil tillage needs a radical change for sustainability," Agriculturae Conspectus Scientificus, vol. 73, no. 3, pp. 131-136, 2008.

[44] M. Birkás, "Earthworm activity in sugar beet fields," in Bevezet”o a Talajmúvelés, c. fejezethez, p. 18.10.9, Agrofórum, 2007.

[45] M. Birkás, J. Antal, and I. Dorogi, "Conventional and reduced tillage in Hungary-a review," Soil and Tillage Research, vol. 13, no. 3, pp. 233-252, 1989.

[46] M. Birkás, et al., Environmentally-Sound Adaptable Tillage, Akadémiai, Budapest, Hungary, 2008. 

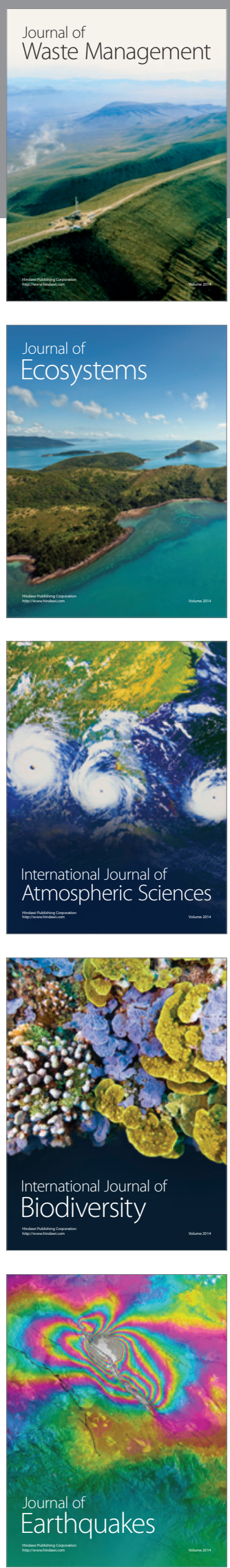
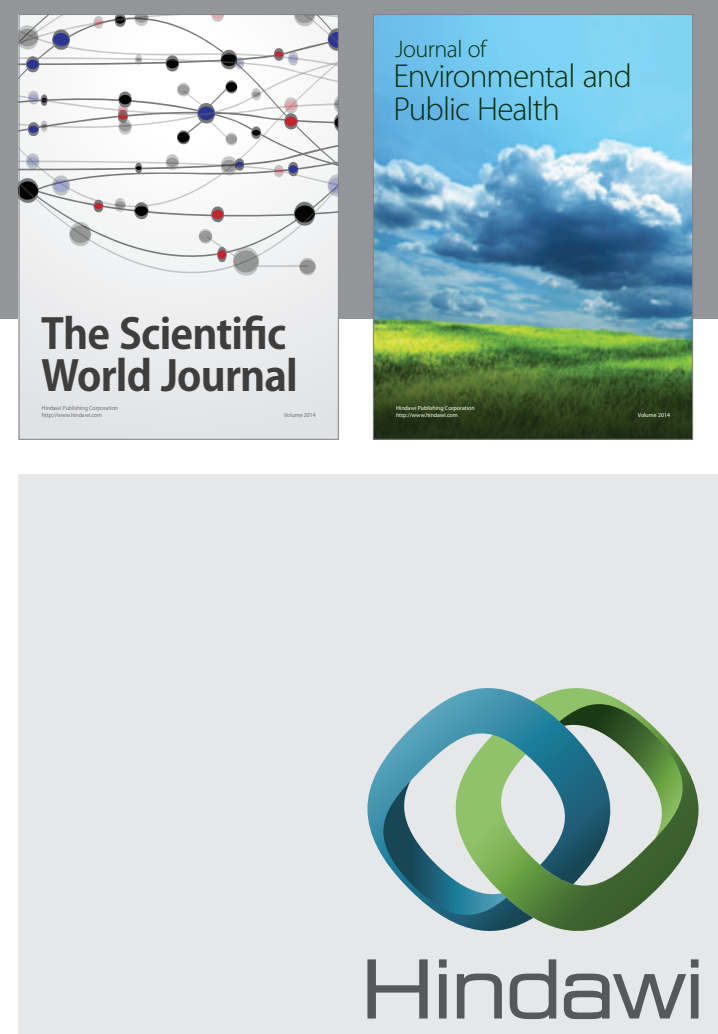

Submit your manuscripts at

http://www.hindawi.com
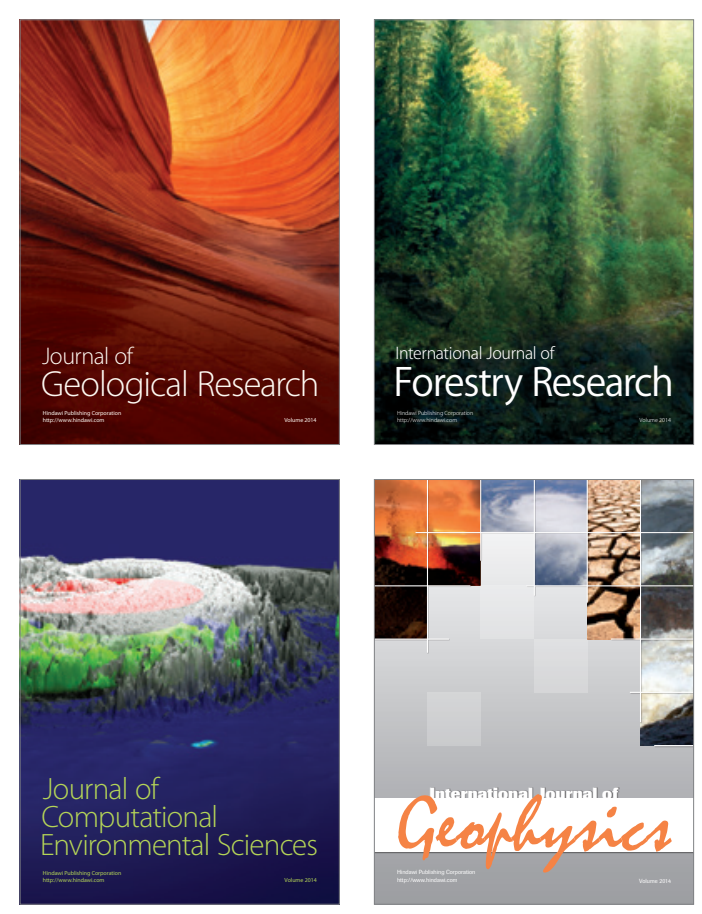
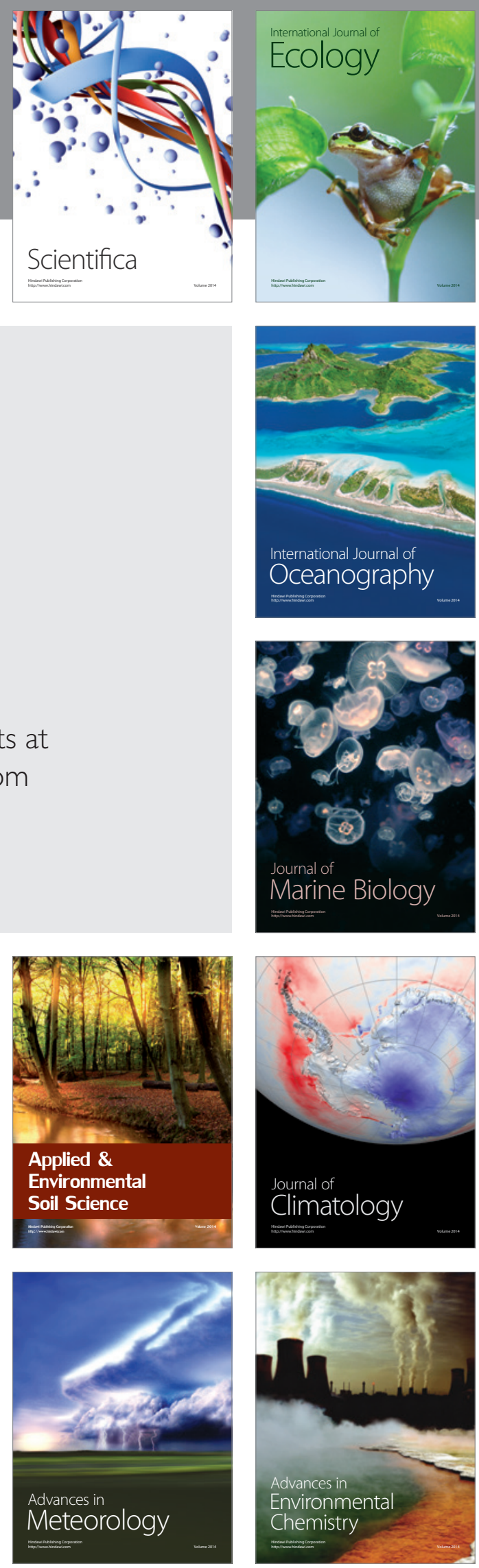